\title{
Ecological stability of Stevia in Ukraine
}

\author{
M. Roik, \\ Academician of the NAAS, Doctor of Agricultural Sciences \\ Institute of Bioenergetic Cultures and Sugar Beet NAAS \\ I. Kuznetsova, \\ candidate of technical sciences \\ National Academy of Agrarian Sciences of Ukraine
}

The purpose. Study of ecological stability of Stevia of cultivar Bereghinia as a result of interaction of system «plant - ecological environment». Methods. Field, calculus. Results. Influence of seed spacing of plants of Stevia and agroclimatic zones of Ukraine on maturity and technological quality is studied. It is shown that in climatic conditions of Ternopol oblast plants of Stevia attain maturity for 5 days earlier than in Kiev and Vinnitsa oblasts. That is stipulated by optimum May-June temperature $\left(15-17^{\circ} \mathrm{C}\right)$ for vegetation growth of plants of Stevia. It is fixed that more stable pliability plants of Stevia manifest in subzone of unreliable moistening at seed spacing 100000 seeds/hectare $(0,388 ; 0,397)$. Conclusions. It is fixed that optimum seed spacing of plants for subzone of sufficient and unstable humidification is $45 \times 16 \mathrm{~cm}$ that ensures production of leaves of high quality with PLPm $6,5-7,0 \mathrm{~cm}^{3}$. As to importance of stability Stevia is nonresistant and depending on agricultural methods can change extent of ecological pliability.

Key words: Stevia, seed spacing, ecological pliability, light period, maturity.

Entry. One of basic directions agrarian a sector there is an increase of the productivity and adaptive potential of introduced of agricultural cultures [1]. For Ukraine such culture is stevia, the study of ability of which stably to realize own potential and reaction on changing of terms of growing is important direction. A certain role is herein played by the selection of new varieties, adaptive to the agricultural climatic terms of country. In particular, widespread today in Ukraine for growing of stevia there is a sort of Bereginya of selection of Institute of biotpower cultures and sugar beets of NAAN. And a study of stability of this sort and increase of the productivity due to the improvement of agricultural receptions is a relevant task [2,3].

Method of researches. The field researches from the management of stevia sort of Bereginya the productivity conducted on the experimental areas of experimental economies in Kiev (State enterprise «Agrofirma "Veselinivka»» and the State enterprise the "Experimental economy of "Skvirske"') during 20112015, Winnitca (Maryanivka) during 2008-2015 and Ternopil (LTD. «Neoksvit») during 2013-2015 areas. After the necessity of adaptation of production to the agricultural climatic terms of regions growing of stevia carried out in under the zone of the sufficient (Winnitca and Ternopil areas: 560-600 mm of fallouts, a vegetation period is $380-450 \mathrm{~mm}$, sum of temperatures over $10{ }^{\circ} \mathrm{C}$ it is $\left.2300-2500{ }^{\circ} \mathrm{C}, \mathrm{HTK}=1,3-1,5\right)$ and unsteady (Kiev area: $480-500 \mathrm{~mm}$, HTK=1,0-1,1) moistening.

Researches conducted in accordance with the generally accepted methods: «Method of field experiment» [4], «Methods of leadthrough of researches in a beet grower» [5], For the receipt of seedling utillized the seed of stevia it is got from experimental areas, which answered the requirements of DSTU 4775:2007. A technical ripeness was expected after a method by the selections of vegetable plants [6]. In obedience to the method of the field two factors experience determined influence of density of seating after three charts $(45 \times 18,45 \times 16,45 \times 12)$ on its quality. Seating of plants in the opened soil carried out on May, $20-25$ by hand. Poured during growth of stevia carried out from a calculation $0,45-0,5$ I on one plant. Biometrical description of plants was set after 12-22 plants for every variant. The productivity of surface part was expected the method of collection of plants [7] after And flowering phases - And ten-day period of July.

By MathCad15 software these indexes are expected for the stevia sort of Bereginya, reared in the agricultural climatic terms of the Winnitca, Kiev and Ternopil areas. 
Results of researches. Given, the got in the field terms show influence of density of seating of plants on their attachment. In particular, in the conditions of the sufficient moistening (tabl. 1) plants have a higher level of attachment (94-97\%) landed after a chart $45 \times 16$. At the fluidized seating $(45 \times 18)$ the productivity is $95 \%$, that conditioned by its genotype. At such method of seating of plant get the least mass of the collected surface part, and accordingly, low productivity of $0,97-1,1 \mathrm{t} /$ hectare of dry sheets. Their productivity (not more than $91 \%)$ goes down at the terms of more concentrated placing of plants $(45 \times 12)$, mass of surface part grows on $23-24 \%$ and the productivity to 1,3 t/hectar. In addition, more concentrated seating of plants results in the decline of area of puff surface to $4,6 \mathrm{~cm}^{3}$ and the same worsens quality of sheets.

In seedling age more скоростиглі plants are selected a compact structure with the sheets of the rounded form. The technical ripeness of plants is expected shows close values for three variants of seating and hesitates scope from 60 to 81 days. The range of annual change of value of technical ripeness shows that after more fluidized seating of plant quick develop and arrive at a technical ripeness (60-75 days), that on 6 days quick. An exception is made 2011 and 2015, when technical ripeness for plants landed after a chart $45 \times 12$ treads before on 3-5 days, than for more fluidized seating.

Tabl. 1. Estimation of adaptive ability of stevia in under the zone $i$ of the sufficient moistening

\begin{tabular}{|c|c|c|c|c|c|c|}
\hline Year & $\begin{array}{c}\text { Density, } \\
\text { sm }\end{array}$ & $\begin{array}{c}\text { Liveliness, } \\
\%\end{array}$ & $\begin{array}{c}\text { Mass of fresh } \\
\text { shredded ground part, } \\
\text { kg }\end{array}$ & $\begin{array}{l}\text { Productivity of } \\
\text { sheets dried, } \\
\text { t/hectare }\end{array}$ & $\begin{array}{l}\text { Technical } \\
\text { ripeness, } \\
\text { days }\end{array}$ & $\begin{array}{l}\text { ALS, } \\
\text { cM3 }\end{array}$ \\
\hline \multicolumn{7}{|c|}{ Winnitca area } \\
\hline \multirow[t]{3}{*}{2008} & $45 \times 18$ & 95 & $690,08 \pm 0,23$ & $1,1 \pm 0,22$ & 60 & 7,92 \\
\hline & $45 \times 16$ & 95 & $839,04 \pm 0,26$ & $1,3 \pm 0,25$ & 64 & 6,84 \\
\hline & $45 \times 12$ & 89 & $752,05 \pm 0,21$ & $1,13 \pm 0,2$ & 81 & 5,12 \\
\hline \multirow[t]{3}{*}{2009} & $45 \times 18$ & 93 & $667,4 \pm 0,18$ & $1,0 \pm 0,19$ & 68 & 7,85 \\
\hline & $45 \times 16$ & 97 & $842,93 \pm 0,2$ & $1,3 \pm 0,18$ & 69 & 6,81 \\
\hline & $45 \times 12$ & 90 & $868,32 \pm 0,23$ & $1,3 \pm 0,22$ & 72 & 4,95 \\
\hline \multirow[t]{3}{*}{2010} & $45 \times 18$ & 92 & $651,36 \pm 0,24$ & $0,97 \pm 0,23$ & 68 & 7,74 \\
\hline & $45 \times 16$ & 95 & $812,25 \pm 0,19$ & $1,2 \pm 0,2$ & 71 & 6,79 \\
\hline & $45 \times 12$ & 88 & $854,3 \pm 0,17$ & $1,3 \pm 0,19$ & 80 & 4,99 \\
\hline \multirow[t]{3}{*}{2011} & $45 \times 18$ & 90 & $659,81 \pm 0,2$ & $1,0 \pm 0,21$ & 70 & 8,02 \\
\hline & $45 \times 16$ & 94 & $826,26 \pm 0,25$ & $1,2 \pm 0,23$ & 75 & 6,68 \\
\hline & $45 \times 12$ & 86 & $914,0 \pm 0,22$ & $1,3 \pm 0,2$ & 72 & 5,13 \\
\hline \multirow[t]{3}{*}{2012} & $45 \times 18$ & 87 & $640,53 \pm 0,23$ & $1,0 \pm 0,22$ & 65 & 8,27 \\
\hline & $45 \times 16$ & 94 & $837,12 \pm 0,27$ & $1,3 \pm 0,25$ & 64 & 6,81 \\
\hline & $45 \times 12$ & 93 & $881,28 \pm 0,24$ & $1,4 \pm 0,23$ & 67 & 5,09 \\
\hline \multirow[t]{3}{*}{2013} & 45õ18 & 86 & $651,46 \pm 0,21$ & $0,97 \pm 0,2$ & 72 & 8,18 \\
\hline & $45 \times 16$ & 96 & $839,0 \pm 0,23$ & $1,3 \pm 0,22$ & 69 & 6,79 \\
\hline & $45 \times 12$ & 90 & $885,4 \pm 0,26$ & $1,3 \pm 0,24$ & 74 & 4,93 \\
\hline \multirow[t]{3}{*}{2014} & $45 \times 18$ & 87 & $624,7 \pm 0,18$ & $0,98 \pm 0,2$ & 69 & 8,19 \\
\hline & $45 \times 16$ & 97 & $801,66 \pm 0,15$ & $1,3 \pm 0,17$ & 67 & 6,81 \\
\hline & $45 \times 12$ & 92 & $897,62 \pm 0,19$ & $1,3 \pm 0,16$ & 72 & 4,88 \\
\hline \multirow[t]{3}{*}{2015} & $45 \times 18$ & 89 & $648,67 \pm 0,23$ & $0,97 \pm 0,21$ & 72 & 7,55 \\
\hline & $45 \times 16$ & 95 & $840,0 \pm 0,19$ & $1,2 \pm 0,21$ & 73 & 6,75 \\
\hline & $45 \times 12$ & 91 & $903,96 \pm 0,21$ & $1,3 \pm 0,18$ & 68 & 4,62 \\
\hline \multicolumn{7}{|c|}{ Ternopil area } \\
\hline \multirow[t]{2}{*}{2013} & $45 \times 18$ & 83 & $648,0 \pm 0,15$ & $1,0 \pm 0,17$ & 76 & 7,45 \\
\hline & $45 \times 16$ & 95 & $854,9 \pm 0,28$ & $1,3 \pm 0,26$ & 72 & 6,87 \\
\hline
\end{tabular}




\begin{tabular}{|c|c|c|c|c|c|c|}
\hline & $45 \times 12$ & 90 & $871,5 \pm 0,24$ & $1,32 \pm 0,22$ & 72 & 5,53 \\
\hline \multirow{3}{*}{2014} & $45 \times 18$ & 88 & $672,3 \pm 0,2$ & $1,02 \pm 0,24$ & 73 & 7,45 \\
\cline { 2 - 7 } & $45 \times 16$ & 94 & $839,3 \pm 0,22$ & $1,3 \pm 0,25$ & 71 & 6,53 \\
\cline { 2 - 7 } & $45 \times 12$ & 87 & $844,1 \pm 0,19$ & $1,3 \pm 0,21$ & 71 & 4,91 \\
\hline \multirow{3}{*}{2015} & $45 \tilde{1} 18$ & 89 & $654,0 \pm 0,18$ & $1,0 \pm 0,19$ & 70 & 7,34 \\
\cline { 2 - 7 } & $45 \times 16$ & 96 & $794,8 \pm 0,24$ & $1,2 \pm 0,17$ & 71 & 7,35 \\
\cline { 2 - 7 } & $45 \times 12$ & 92 & $822,0 \pm 0,2$ & $1,24 \pm 0,21$ & 71 & 5,64 \\
\hline
\end{tabular}

Changes adaptive ability of stevia in the conditions of the Ternopil area, regardless, that is in one under the zone with Winnitca. In particular, for seating of seedling after the chart of $45 \times 18$ liveliness in prolong three years changed scope from 83 to $89 \%$, after $45 \times 16$ - from 94 to $96 \%$, after $45 \times 12$ - from 87 to $92 \%$. Thus the productivity of dry sheets from a hectare for fluidized density did not change and made $1 \mathrm{t} /$ hectare, and for density 100 and 120 thousands of pies./hectare it was close from 1,2 to $1,32 \mathrm{t} /$ hectare. It is necessary to mark also, that plants are reared in the Ternopil area have less duration of technical ripeness which makes 70-76 days. Exactly in the Ternopil area in May-June an average daily temperature was provided $15-17{ }^{\circ} \mathrm{C}$, what is friendly to development of vegetable vehicle, that accordingly, reduced a technical ripeness on 5 days. Thus, for under the zone of the sufficient moistening more optimum chart of seating of stevia after productive and technological parameters is $45 \times 16$.

The change of under the zone of moistening in growing of stevia results in the change of basic indexes which control of efficiency of growing is carried out after (tabl. 2). In particular, in the Kiev area liveliness of seedling the value of which does not exceed $90 \%$ goes down at the fluidized $(45 \times 18)$ seating.

Tabl. 2. Productivity of stevia in under the zone of the insufficient moistening

\begin{tabular}{|c|c|c|c|c|c|c|}
\hline Year & $\begin{array}{c}\text { Density, } \\
\text { see }\end{array}$ & $\begin{array}{c}\text { Liveliness, } \\
\%\end{array}$ & $\begin{array}{c}\text { Mass of fresh } \\
\text { shredded ground } \\
\text { part, kg }\end{array}$ & $\begin{array}{c}\text { Productivity of } \\
\text { sheets dried, } \\
\text { t/hectare }\end{array}$ & $\begin{array}{c}\text { Technical } \\
\text { ripeness, } \\
\text { days }\end{array}$ & ALS, cM3 \\
\hline 2011 & $45 \times 18$ & 86 & $624,7 \pm 0,2$ & $0,95 \pm 0,21$ & 67 & 7,92 \\
\cline { 2 - 7 } & $45 \times 16$ & 93 & $801,7 \pm 0,15$ & $1,2 \pm 0,17$ & 69 & 6,54 \\
\cline { 2 - 7 } & $45 \times 12$ & 91 & $897,6 \pm 0,18$ & $1,4 \pm 0,16$ & 66 & 5,08 \\
\hline 2012 & $45 \times 18$ & 87 & $648,7 \pm 0,25$ & $1,0 \pm 0,22$ & 74 & 8,24 \\
\cline { 2 - 7 } & $45 \times 16$ & 96 & $840,0 \pm 0,23$ & $1,3 \pm 0,21$ & 73 & 6,75 \\
\cline { 2 - 7 } & $45 \times 12$ & 93 & $903,96 \pm 0,26$ & $1,4 \pm 0,24$ & 73 & 5,01 \\
\hline 2013 & $45 \times 18$ & 85 & $629,0 \pm 0,18$ & $0,95 \pm 0,2$ & 74 & 8,11 \\
\cline { 2 - 7 } & $45 \times 16$ & 94 & $812,2 \pm 0,21$ & $1,2 \pm 0,23$ & 76 & 6,69 \\
\cline { 2 - 7 } & $45 \times 12$ & 92 & $867,7 \pm 0,19$ & $1,3 \pm 0,2$ & 75 & 4,85 \\
\hline 2014 & $45 \times 18$ & 89 & $660,7 \pm 0,24$ & $1,0 \pm 0,22$ & 76 & 8,1 \\
\cline { 2 - 7 } & $45 \times 16$ & 97 & $833,2 \pm 0,2$ & $1,3 \pm 0,22$ & 73 & 6,73 \\
\cline { 2 - 7 } & $45 \times 12$ & 89 & $839,5 \pm 0,17$ & $1,3 \pm 0,19$ & 74 & 4,7 \\
\hline 2015 & $45 \times 18$ & 87 & $643,8 \pm 0,26$ & $1,0 \pm 0,24$ & 72 & 7,57 \\
\cline { 2 - 7 } & $45 \times 16$ & 95 & $805,6 \pm 0,23$ & $1,2 \pm 0,21$ & 76 & 6,51 \\
\cline { 2 - 7 } & $45 \times 12$ & 93 & $864,9 \pm 0,21$ & $1,3 \pm 0,2$ & 74 & 4,45 \\
\hline
\end{tabular}

Insignificant is insignificantly worsened for more concentrated seating of seedlings. However, the higher productivity of dry sheets is provided to $1,2-1,3 \mathrm{t}$ from one hectare for the chart of seating $45 \times 16$ and $1,3-1,4$ $t$ for the chart of seating $45 \times 12$. For plants landed after густотою 80 and 100 thousands of pies./hectare more perceptible was 2011, that was instrumental in more rapid achievement of technical ripeness. At less density a plant has a greater area for forming of bush which is instrumental in the increase of puff surface to 
$8,2 \mathrm{~cm}^{3}$. In addition, duration of technical ripeness which for all of variants of seating makes 66-76 days goes down. It is marked, that technical ripeness of plants landed after a chart $45 \times 18$ grows on 1-3 days.

On Kiev of plant of stevia at density of seating 80-100 thousands of pies/hectare arrive at height 45-55 see, have middle mass of dry plant from 27 to a 37 gramme and basic dry sheet from 0,028 to a 0,04 gramme and ALS - 4,4-8,3 $\mathrm{cm}^{3}$. However, have a greater particle of dry surface part in general mass - 48$67 \%$. Consequently, greater густота of seating of plants complicates the production of large sheets and reduces them technological quality.

Ecological variability characterizes the variation of the characteristics of the Beregin family of domestic selection as a result of the interaction of the systems "plant - ecological environment", characteristic of a certain soil-climatic zone. According to S.A. Eberharta and W.A. Russella estimates of ecological plasticity and plant stability variations, based on dispersion and regression analysis, and gives an opportunity to evaluate their reactions in different growing conditions. Ecological ductility shows the average reaction of plants to change environmental conditions. Stability of plasticity shows the deviation of empirical data under specific environmental conditions from environmental plasticity, that is, from the average reaction to changing conditions of cultivation [8]. Model S.A. Eberharta and W.A. Russella is used to assess the adaptive capacity of varieties and hybrids of spring barley [9, 10], vegetable crops [11], and others. In Ukraine, stevia is a poorly developed culture and the study of the influence of the conditions of cultivation of the Beregin species is a topical issue.

Results of the mathematical processing of experimental data in relation to liveliness of seedlings and it technological ripeness depending on a year, густоти of seating and agricultural climatic area it is presented in a tabl 3. The best liveliness plants discover in under the zone of the unsteady moistening at density of seating 100 thousands of pies./hectare $(0,388,0,397)$. In the conditions of under the zone of the sufficient moistening 100 thousands of pies. find out greater plasticity of plant at density of pies./hectare (Winnitca $0,21,0,217$; Ternopil $-0,215$ ). In obedience to the scale of gradation of size under the zone of the unsteady moistening is characterized the coefficient of ecological stability of the landed territory [12] for stevia as unsteady stable, and under the zone of the sufficient moistening as unstable. 


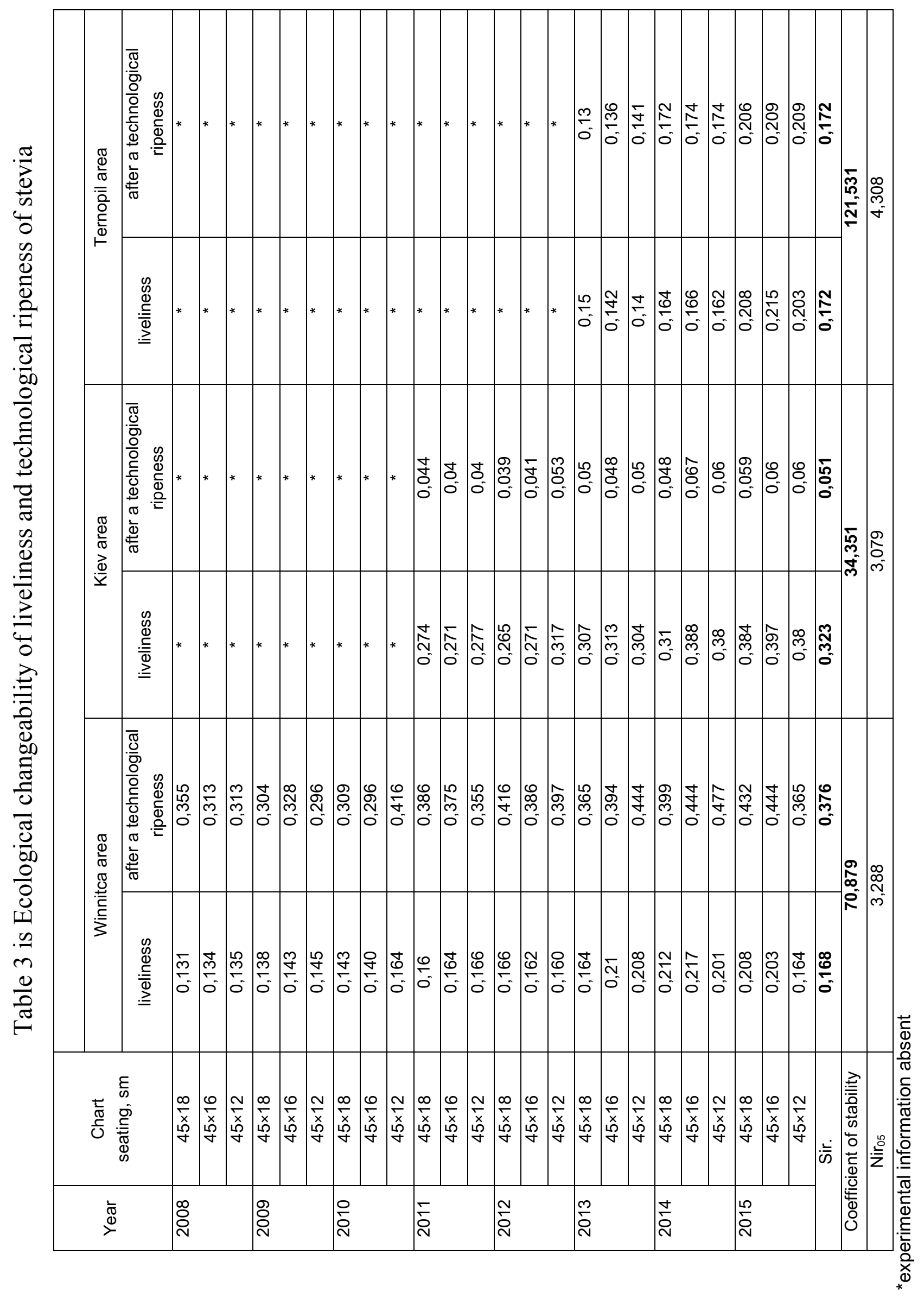


It is known that than higher value of degree of plasticity, that plants of certain sort more sensible to the changes of terms growings after years [9]. The got is given after liveliness of seedlings show that plants show a greater sensitiveness in the conditions of under the zone of the unsteady moistening and more small in the conditions of under the zone of the sufficient moistening. It is necessary to mark, that the degree of ecological plasticity at liveliness plants grows in all of experiments with the years of leadthrough of researches and in the conditions of the Kiev and Ternopil areas quick than in the conditions of the Winnitca area. In same queue, liveliness influences on the degree of plasticity after a technological ripeness. To achievement of technological ripeness of plant it is found out a greater sensitiveness in the conditions of under the zone of the sufficient moistening.

On the sign of stability greater value certainly in the climatic terms of the Ternopil area and less than in the conditions of Kiev. It is marked, that a capacity of plants for ecological plasticity in the agricultural climatic areas of Ukraine is not stable, and depending on the elements of technology of growing can change. An error of experiments is rationed and does not exceed $5 \%$.

\section{Conclusions}

Taking into account the conducted researches in two under the zone of moistening of Ukraine and Conception of the rational use of the landed resources, effective is application of density of seating of stevia 100 thousands of pies./hectare. It enables to get a plant with good physiology properties for which the terms of receipt of sheets of stevia of high technological quality are provided with the area of puff surface of about $8 \mathrm{~cm}^{3}$. It is rotined that more concentrated seating of plants results in the decline of area of puff surface to $4,4 \mathrm{~cm}^{3}$, that reduces technological quality of sheets. It is marked, that in the climatic terms of the Ternopil area in May-June an average daily temperature was $15-17^{\circ} \mathrm{C}$, what is optimum light period for vegetation development of tropical plants and instrumental in more rapid (on 5 days) achievement of technical ripeness.

It is set that after the degree of plasticity in relation to liveliness plants, to the stevia sort of Bereginya more sensible to the terms of under the zone of the not proof moistening $(0,397)$ and less to the terms of under the zone of the sufficient moistening $(0,217)$ at density of seating 100 thousands of pies./hectare. With the increase of year of seating in the certain agricultural climatic terms of under the zone of moistening the value of degree of plasticity grows after liveliness, that characterizes adaptive ability of plants. It is rotined that the coefficients of plasticity after liveliness influence on the degree of plasticity after the technological ripeness of plants in the agricultural climatic terms of Ukraine. In particular, it is found out the greater sensitiveness of plant in the conditions of under the zone of the sufficient moistening. It is marked, that ability of plants to ecological plasticity of agricultural climatic areas of Ukraine is not stable and depending on the elements of technology of growing can change.

\section{Bibliography}

1. Brandle J.E., Starratt A.N., Gijzen M. Stevia rebaudian: Its agriculural, biological and chemical properties/Canadian jornal of plant science. 1998. - p. 527-536.

2. Royik M.V. Znachennya steviyi (Stevia Rebaudiana Bertroni) u narodnomu hospodarstvi/M.V. Royik, I.V Kuznyetsova//Tezy mizhnarodnoyi naukovo-praktychnoyi Internet-konferentsiyi «Nauka na sluzhbi sil's'koho hospodarstva». - Mykolayiv, - 2013. s. 23-24.

3. Royk N.V. Model' formyrovanyya pokazateley kachestva lyst'ev stevyy/N.V. Royk, Y.V. Kuznetsova//Lucrari stiintifice volumul 42 (1). - Chisinau, 2015. P. 243-246.

4. Dospekhov B.A. Metodyka opыtnoho dela. M.: Kolos, 1977. - $416 \mathrm{~s}$.

5. Metodyky provedennya doslidzhen' u buryakivnytstvi/M.V. Royik, N.H. Hizbulin, V.M. Sinchenko ta in.; za zah. Red. M.V. Royika ta N.H. Hizbulina. - K.: FOP Korzun D.Yu., 2014. - 374 s.

6. Suchasni metody selektsiyi ovochevykh i bashtannykh kul'tur/za red. chlena-korespondenta NAAN Horovoyi T.K. ta k.s.-h.n. Yakovenka K.I. - Kharkiv. 2001. - s. 642.

7. Metodyka doslidnoyi spravy $v$ ovochivnytstvi i bashtannytstvi/za red. H.L. Bondarenka, K.I. Yakovenka. Avtory: V.Yu. Honcharenko, V.Yu. Bondarenko, V.V. Khareba, Z.D. Sych ta in..//- Kh.: Osnova, 2001. $369 \mathrm{~s}$. 
8. Eberhart S.A. Stability parameters for comparing varieties/S.A. Eberhart, W.A. RusselV/Crop Sci. 1966. - V. 6, №1. - P. 36-40.

9. Marenyuk O.B. Plastychnist' ta stabil'nist' kil'kisnykh oznak kolektsiynykh zrazkiv yachmenyu yaroho v umovakh pidvyshchenoyi kyslotnosti hruntiv/O.B. Marenyuk//Selektsiya i nasinnytstvo. 2014. Vyp. 16. S. 7781.

10. Vazhenina O.Ye. Ekolohichna stabil'nist' elementiv produktyvnosti sortiv yachmenyu yaroho ta efektyvnist' selektsiyi na osnovi yikh vykorystannya v hibrydyzatsiyi/O.Ye. Vazhenina, M.R. Kozachenko, N.I. Vas'ko, O.H. Naumova//Visnyk Sums'koho natsional'noho ahrarnoho universytetu. Seriya "Ahronomiya i biolohiya», vypusk 11 (26), 2013. S. 164-169.

11. Horova T.K. Parametry ekolohichnoyi plastychnosti ta stabil'nosti vrozhaynosti koreneplodiv u hibrydiv F1 vydu RAPHANUS SATIVUS L./T.K. Horova, N.O. Kyryukhina//VISNYK Poltavs'koyi derzhavnoyi ahrarnoyi akademiyi. \# 2. 2010. S. 18-20.

12. Volkov S.M., Khlystun V.M., Ulyukayev V.Kh. Osnovb zemlevladenyya y zemlepol'zovanyya. - M.: Nauka, 1990. - $143 \mathrm{~s}$. 